\title{
Clinical manifestations of four patients diagnosed with early-onset sarcoidosis or sarcoid-like syndrome
}

\author{
Sara Murias ${ }^{1 *}$, Rosa Alcobendas ${ }^{1}$, Agustin Remesal ${ }^{1}$, Jesus Peralta ${ }^{2}$, Susana Noval ${ }^{2}$, Juan Ignacio Arostegui ${ }^{3}$,
} Rebeca Rodriguez-Pena ${ }^{4}$, Ana Mendez ${ }^{5}$, Rosa Merino ${ }^{1}$

From 21st European Pediatric Rheumatology (PReS) Congress

Belgrade, Serbia. 17-21 September 2014

\section{Introduction}

Sarcoidosis is a rare multisystemic granulomatous disease. Pulmonary involvement is common in adults, but any organ can be affected.

\section{Objectives}

To describe the main features of 4 pediatric patients diagnosed with early-onset sarcoidosis (EOS) or sarcoid-like syndrome.

\section{Methods}

Medical charts were reviewed.

\section{Results}

Four patients wer enrolled, 2 female (cases 1 and 2) and 2 male (cases 3 and 4). Their main characteristics are shown in table 1. The age at disease onset was 1.5, 10, 0.6 and 11 years respectively. The time until diagnosis ranged from 4 days to 8 years. The two cases with EOS (1 and 3) had been previously diagnosed as Juvenile Idiopathic Arthritis. Both started at a short age with the classical triad and carried a heterozygous gain-of-function NOD2 mutation. Patient 2 seemed to be a late-onset sarcoidosis but persistent hypogammaglobulinemia and poor antibody production suggested a CVID, despite she did not suffer

Table 1 Main features of the four enrolled children

\begin{tabular}{|c|c|c|c|c|c|}
\hline & Clinical data & Analytical data & ACE & Non-caseating granulomata & Diagnosis \\
\hline \multirow[t]{2}{*}{1} & Arthritis, rash, uveitis & Heterozygous p.R334Q & 27.5 & Skin & EOS \\
\hline & & Mutation at NOD2 gene & & & \\
\hline \multirow[t]{4}{*}{2} & Splenomegaly, & Lymphopenia & & & CVID \\
\hline & lymphadenopathy, & Thrombocytopenia & & & Sarcoid like syndrome \\
\hline & interstitial/nodular & Hypogammaglobulinemia & 92 & Lung & \\
\hline & lung disease & Poor antibody responses & & & \\
\hline \multirow[t]{4}{*}{3} & Arthritis, rash, uveitis & & & & \\
\hline & & Heterozygous p.C495Y & 19 & Skin & Blau's syndrome \\
\hline & & Mutation at NOD2 gene & & Synovial & \\
\hline & & & & Liver & \\
\hline 4 & $\begin{array}{l}\text { Right facial paralysis, parotid enlargement, } \\
\text { uveitis, high fever }\end{array}$ & & 74.8 & & Heerfordt's syndrome \\
\hline
\end{tabular}

$\mathrm{ACE}=$ angiotensin converting enzyme serum level (normal 10-50 IU/I)

CVID = common variable immunodeficiency

${ }^{1}$ Pediatric Rheumatology, University Hospital La Paz, Madrid, Spain

Full list of author information is available at the end of the article

(c) 2014 Murias et al; licensee BioMed Central Ltd. This is an Open Access article distributed under the terms of the Creative Commons 
from recurrent infections. Other granulomatous lung diseases were dismissed in this case. Finally, diagnosis in patient 4 was made according to his clinical manifestations and the slight increase in ACE level.

\section{Conclusion}

Diagnosis of sarcoidosis in pediatric patients is often delayed because the disease is not suspected. Pulmonary involvement occurs less frequently in pediatric than in adults patients. This condition requires multidisciplinary management.

\section{Disclosure of interest}

None declared.

\section{Authors' details}

${ }^{1}$ Pediatric Rheumatology, University Hospital La Paz, Madrid, Spain. ${ }^{2}$ Pediatric Ophthalmology, University Hospital La Paz, Madrid, Spain. ${ }^{3}$ Immunology, Hospital Clinic, Barcelona, Spain. ${ }^{4}$ Immunology, General Pediatrics, University Hospital La Paz, Madrid, Spain. ${ }^{5}$ TBC.

Published: 17 September 2014

doi:10.1186/1546-0096-12-S1-P293

Cite this article as: Murias et al:: Clinical manifestations of four patients diagnosed with early-onset sarcoidosis or sarcoid-like syndrome.

Pediatric Rheumatology 2014 12(Suppl 1):P293.

Submit your next manuscript to BioMed Central and take full advantage of:

- Convenient online submission

- Thorough peer review

- No space constraints or color figure charges

- Immediate publication on acceptance

- Inclusion in PubMed, CAS, Scopus and Google Scholar

- Research which is freely available for redistribution

Submit your manuscript at www.biomedcentral.com/submit 